\title{
Bleaching susceptibility of aquarium corals collected across northern Australia
}

\author{
Morgan S. Pratchett ${ }^{1}(0)$ Ciemon F. Caballes $^{1} \cdot$ Stephen J. Newman $^{2}(1) \cdot$ \\ Shaun K. Wilson ${ }^{3,4} \mathbb{D}^{-} \cdot$ Vanessa Messmer $^{1} \cdot$ Deborah J. Pratchett $^{1}$
}

Received: 1 December 2019/Accepted: 15 April 2020/Published online: 30 April 2020

(C) The Author(s) 2020

\begin{abstract}
There are a wide range of Scleractinian corals that are collected for the global reef aquarium market, often from non-reefal environments. The sustainability of coral harvesting is potentially threatened by increasing anthropogenic disturbances and climate change, though it is unknown to what extent many commonly harvested corals are susceptible to environmental change, or actually bleach during marine heatwaves. In this study, we experimentally tested the temperature sensitivity and bleaching susceptibility of six coral species (Homophyllia australis, Micromussa lordhowensis, Catalaphyllia jardinei, Trachyphyllia geoffroyi, Duncanopsammia axifuga, and Euphyllia glabrescens), which are important components of the aquarium coral fisheries across northern Australia, in Western Australia, the Northern Territory, and/or Queensland. Interspecific differences were evident in the temperature sensitivity and bleaching susceptibility among the study species. Homophyllia australis, and M. lordhowensis were found to be particularly susceptible to elevated
\end{abstract}

Topic Editor Andrew Hoey

Morgan S. Pratchett

morgan.pratchett@jcu.edu.au

1 ARC Centre of Excellence for Coral Reef Studies, James Cook University, Townsville, QLD 4811, Australia

2 Western Australian Fisheries and Marine Research Laboratories, Department of Primary Industries and Regional Development, Government of Western Australia, Hillarys, WA 6025, Australia

3 Marine Science Program, Department of Biodiversity, Conservation and Attractions, Western Australian Government, Kensington, WA 6151, Australia

4 Oceans Institute, University of Western Australia, Crawley, WA 6009, Australia temperatures, whereby all corals subjected to elevated temperatures died within the course of the experimental treatment $(75$ d). Catalaphyllia jardinei and E. glabrescens also exhibited significant increases in mortality when exposed to elevated temperatures, though some of the corals did survive, and $C$. jardinei mostly died only after exposure to elevated temperatures. The other species ( $T$. geoffroyi and $D$. axifuga) exhibited marked bleaching when exposed to elevated temperatures, but mortality of these corals was similar to that of conspecifics held at ambient temperatures. This study highlights the potential for environmental change to impact the sustainability and viability of Australian coral harvest fisheries. More importantly, this study highlights the need for specific and targeted in situ monitoring for important stocks of coral fishery target species, to assess their vulnerability to fishery and fisheryindependent effects.

Keywords Controlled experiment $\cdot$ Scleractinia . Temperature $\cdot$ Light intensity $\cdot$ Survivorship

\section{Introduction}

Mass coral bleaching is an increasingly familiar and recurring phenomenon, whereby many different species of zooxanthellate corals lose their endosymbionts and associated photosynthetic pigments (Glynn 1984), mainly in response to environmental stress, including freshwater inundation, aerial exposure, sedimentation and anomalous temperatures (Wiedenmann et al. 2013). The severity, extent and frequency of mass coral bleaching has increased since the 1980s (Hughes et al. 2018a) in line with ocean warming and increasing incidence of marine heatwaves (Heron et al. 2016; Hobday et al. 2018; Skirving et al. 
2019). Marine heatwaves are now the foremost cause of mass coral bleaching and elevated coral mortality (Hughes et al. 2018a, b), threatening the population viability of vulnerable coral species and undermining the ecological integrity and function of reef ecosystems. Climate-induced coral bleaching, as well as other causes of coral mortality, may also directly undermine the sustainability and viability of harvest fisheries that collect corals from the wild, mainly for home and public aquaria (Harriott 2003; Rhyne et al. 2012).

International ornamental and aquarium coral fisheries involve the annual trade of hundreds of thousands of small coral pieces and are worth millions of dollars (Wood et al. 2012). An increasing portion of the coral sold comes from aquaculture; however the majority is still collected from the wild, from countries like Indonesia and the Philippines (Rhyne et al. 2012). In Australia, coral harvesting is a relatively minor cause of coral loss, and the annual biomass of coral removed is negligible compared to reef-wide levels of coral biomass and productivity (Harriott 2003). For the Queensland Coral Fishery (QCF) the annual Total Allowable Commercial Catch (TACC) is 200 tonnes, with fishing activity spread across a large area, and prohibited within no-take marine reserves (QDEEDI 2009). Reported catches have also been $<50 \%$ of the TACC throughout the last decade (DAF 2018). Coral fisheries in other jurisdictions (Western Australia, Northern Territory, and the Coral Sea) have much smaller quotas. Despite the limited overall harvesting, it is possible that specific species may be overexploited where harvesting is concentrated on rare species. Aquarium corals are mostly selected based on appearance, especially colour, as well as their amenability to harvesting, transport and maintenance within aquaria. Few jurisdictions have species-specific quotas, and there is insufficient knowledge of wild stocks to even propose relevant harvest limits for most species (Roelofs and Silcock 2008). Aside from fisheries effects, widespread and accelerating degradation of coral reef ecosystems is placing increasing pressure on coral fisheries globally, leading to greater public and political scrutiny regarding the sustainability of coral harvesting (Albert et al. 2015). The principal concern relates to the potential risk of localized depletion for vulnerable and slow-growing coral species (Harriott 2003; Garrabou et al. 2017). This concern is further magnified where harvested corals are simultaneously being impacted by fisheries-independent threats, including rapid and accelerating environmental change (Montero-Serra et al. 2019). Importantly, marine heatwaves have caused severe and widespread coral bleaching across Australia in recent years (Hughes et al. 2017), but it is largely unknown how these events impacted many of the corals (other than Acropora spp.) harvested by aquarium coral fisheries.
All zooxanthellate organisms are susceptible to temperature-induced bleaching at some level (Buddemeier and Fautin 1993), and very severe marine heatwaves can cause comprehensive bleaching and mortality across a wide range of different coral species (e.g., Vargas-Angel et al. 2019). There are however, apparent taxonomic differences in the susceptibility and responses of corals to increasing temperature (Loya et al. 2001; Grottoli et al. 2014; Hoey et al. 2016; Claar and Baum 2019). Among common, widespread and well-studied coral taxa, the rank order of bleaching susceptibility (based on the proportion of colonies that bleach or die) appears to be fairly conserved among geographic locations (e.g., McClanahan et al. 2004), whereby Acropora spp. are often the first to bleach and experience the highest mortality rates (Baird and Marshall 2002; Pratchett et al. 2013; Burt et al. 2019; but see Guest et al. 2012; Chou et al. 2016). Conversely, other corals, such as Turbinaria spp. are rarely observed to bleach (e.g., Marshall and Baird 2000) and appear particularly capable of withstanding thermal stress. There are many coral taxa for which we know very little about temperature sensitivity and bleaching susceptibility, mostly because they do not occur on shallow carbonate reefs, where in situ studies of coral bleaching are predominantly conducted (e.g., Hughes et al. 2017; Gilmour et al. 2019; Raymundo et al. 2019; but see Camp et al. 2018). This includes many of the coral taxa that are collected for the aquarium fishery from turbid intertidal habitats.

The purpose of this study was to assess the temperature sensitivity and bleaching susceptibility of six commonly harvested aquarium corals (Homophyllia australis, Micromussa lordhowensis, Catalaphyllia jardinei, Trachyphyllia geoffroyi, Duncanopsammia axifuga, and Euphyllia glabrescens), by exposing each of these coral species to elevated temperatures in aquaria. While such experimental studies are highly constrained in their capacity to assess how corals respond to elevated temperatures in the wild (Camp et al. 2018), there is a paucity of data regarding the bleaching susceptibility of these study species and experimental studies provide the most tractable way to assess relative bleaching susceptibility of poorly studied species.

\section{Methods}

\section{Experimental set-up}

This study was conducted in the Marine Aquarium Research Facility (MARFU) at James Cook University, in Townsville, Australia. Licensed coral collectors in Queensland (both CQ and NQ), WA and NT provided a total of 257 distinct corals (mostly whole colonies or individual polyps, but sometimes fragments) across 6 
different study species (H. australis, M. lordhowensis, $C$. jardinei, T. geoffroyi, D. axifuga, and E. glabrescens) that were transported to Townsville within 1-2 weeks of collection. Where possible, samples of each coral species were obtained from Western Australia (WA), Northern Territory (NT), north Queensland (NQ) and central Queensland (CQ) (Table 1). All corals were mounted on ceramic discs, which were coded to distinguish individual corals and their provenance. Corals (1-2 individuals per species per location) were randomly assigned to each one of 12 different tanks across four different treatments (Fig. 1).

To test the bleaching responses and temperature sensitivity of the different corals, corals within the "heated treatments" were subject to gradual warming $\left(1.0^{\circ} \mathrm{C}\right.$ change per week) until the temperature reached a maximum of $32{ }^{\circ} \mathrm{C}$. The reason for using prolonged heating to relatively high maximum temperatures was intended to explicitly assess interspecific and regional variation in bleaching susceptibility, based on the time until individual corals exhibited bleaching. Temperatures in control tanks started at $25.6{ }^{\circ} \mathrm{C}$, and varied between 25.1 and $27.5{ }^{\circ} \mathrm{C}$ through the course of the experiment. Given most of the study species come from turbid inshore or deeper interreefal habitats, it was possible that bleaching susceptibility would be moderated by the light environment. To test this, we further divided corals into high and low light treatments, whereby the maximum light intensity (measured using a Li-Cor portable light meter during peak irradiance) was $208.0( \pm 10.6 \mathrm{SE})$ and $48.7( \pm 2.8 \mathrm{SE}) \mu \mathrm{mol} \mathrm{m}{ }^{-2}$ $\mathrm{s}^{-1}$, respectively. These different light intensities are equivalent to those used to assess the role of light

Table 1 Identity and provenance of corals used in the controlled bleaching experiment to test for interspecific differences in susceptibility to elevated temperature and light

\begin{tabular}{lccccc}
\hline Species & NT & NQ & CQ & WA & Total \\
\hline Family Lobophyllidae & & & & & \\
$\quad$ Homophyllia australis & & & 17 & & 17 \\
$\quad$ Micromussa lordhowensis & & & 18 & & 18 \\
$\quad \begin{array}{l}\text { Family Merulinidae } \\
\quad \text { Catalaphyllia jardinei }\end{array}$ & 18 & 20 & & 38 \\
$\quad$ Trachyphyllia geoffroyi & & 18 & 23 & 15 & 56 \\
Family Dendrophylliidae & & & & & \\
$\quad$ Duncanopsammia axifuga & 20 & 18 & 19 & 21 & 78 \\
Family Euphyllidae & & & & & \\
$\quad$ Euphyllia glabrescens & & 18 & 16 & 16 & 50 \\
Total & 20 & 72 & 113 & 52 & 257 \\
\hline
\end{tabular}

Source region: $N T$ Northern Territory (Darwin), $N Q$ North Queensland (Cairns), $C Q$ Central Queensland (Mackay), WA Western Australia (Karratha). Corals were equally distributed among the four treatments
(> $180 \mu \mathrm{mol} \mathrm{m}{ }^{-2} \mathrm{~s}^{-1}$ ) in previous experimental bleaching studies (e.g., Wiedenmann et al. 2013), and are approximately equivalent to light regimes recorded in open reef environments versus shaded environments (e.g., within caves) at a depth of $5 \mathrm{~m}$ (Anthony and Hoegh-Guldberg 2003).

All colonies were acclimated to experimental conditions (ambient temperature and low light) for a minimum of 1-week before being subject to high light and/or experimental warming. The day that warming was initiated (April 9th 2018) was set as Day 1, and corals were subject to experimental conditions until Day 75, at which time experimental tanks with high temperatures were reduced to ambient temperatures over $72 \mathrm{~h}$. We then continued to monitor all surviving colonies until Day 150. Corals were inspected every $1-2 \mathrm{~d}$ to record survival, and scored for colour, following Siebeck et al. (2006) every 1-2 weeks. Survival of individual coral colonies was recorded as the sum of the proportion of time a coral survived during the heating experiment plus the proportion of time the coral survived post treatment; i.e. corals that survived to day 75 (end of heating experiment) were assigned a survivorship of 1.0, and corals that survived to day 150 (end of study period) were assigned survivorship of 2.0. Changes in colour were based on changes in colour saturation (measured on a 6-point scale), between initial records taken on Day 1 versus Day 75 (or the last record of colour hue taken prior to mortality). Bleaching was defined as a change in colour saturation of 2 units or more, following Siebeck et al. (2006).

\section{Data analyses}

We modelled colour change and survival in corals as a function of 'Temperature' and 'Light' using linear mixedeffects models (Bates et al. 2015). 'Species', 'Temperature', and 'Light' were included as fixed effects. We also included the individual 'Tank' where the corals were placed as a random effect to account for the non-independence of replicates tested within the same aquarium. 'Region' was not included as a factor since some species were only sourced from one locality (see Table 1). Alternative models were compared using Akaike's information criterion corrected for small sample sizes (AICc) following Burnham and Anderson (2002). Models were fitted using the 'Imer' function (library lme4) in R 3.0.1 (R Core Team 2019). Post hoc comparisons were conducted for survival data using the Tukey method in the $\mathrm{R}$ package emmeans (Lenth et al. 2018).

To better resolve differences in survival among corals, we obtained nonparametric estimates of the shape of the survivorship curves for each coral species under the two temperature treatments using Kaplan-Meier product-limit 


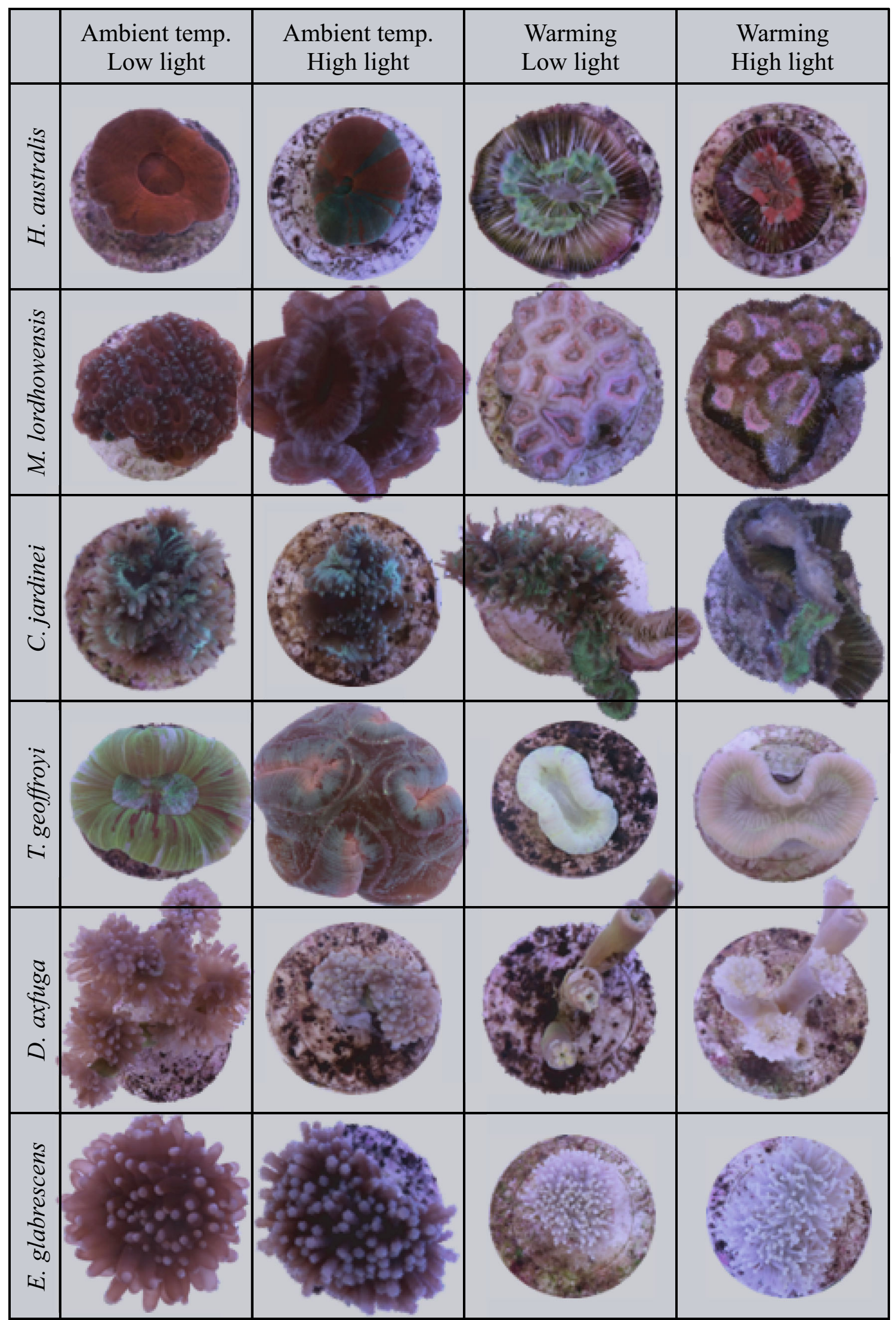


4Fig. 1 Select images of experimental colonies to indicate interspecific differences in responses of the six coral species (H. australis, $M$. lordhowensis, $C$. jardinei, $T$. geoffroyi, $D$. axifuga, and $E$. glabrescens) with exposure to increasing temperature and high levels of light intensity

analysis. The Kaplan-Meier model is based on estimating conditional probabilities at each time point when an event occurs, and taking the product limit of those probabilities to estimate the survival rate at each point in time (Kaplan and Meier 1958). Survival probabilities were calculated using the 'survfit' function in the $\mathrm{R}$ package survival (Therneau 2015) and visualised by plotting survival curves using the 'ggsurvplot' function in the R package survminer (Kassambara et al. 2017). To test whether survival trends were significantly different for each treatment, survival probabilities were compared using the Log-rank test, which takes into account both individuals that died during the course of the experiment and individuals that were still alive at the end of the study, i.e. right-censored data (Walker and Shostak 2010). All plots and analyses were implemented in R 3.0.1 (R Core Team 2019).

To assess interspecific and regional variation in the tolerance of corals to temperature and light treatments, standardised mean differences (SMDs), using Hedges' $G$ (Hedges 1981) as an effect size metric, were calculated using the 'metacont' function in the $\mathrm{R}$ package meta (Schwarzer 2007). Calculated effect sizes and 95\% confidence intervals were used to generate forest plots in $\mathrm{R}$ 3.0.1 (R Core Team 2019).

\section{Results}

\section{Bleaching susceptibility}

A total of 257 small ( $<60 \mathrm{~mm}$ diameter) corals were used in the experiment (Table 1). Of these, 128 (49.8\%) corals exhibited declines in colour saturation through the course of the experiment, with bleaching (where declines in colour saturation were $>2$ ) recorded for 74 corals $(28.8 \%)$. All six species exhibited bleaching (Fig. 2). The incidence of bleaching was consistently higher for corals subject to experimental warming (35.6\%), though $16.67 \%$ of the colonies maintained at ambient temperatures also bleached (Fig. 2). The overall incidence of bleaching (across all treatments) was greatest for $M$. lordhowensis $(38.9 \%$, $n=18)$ and $E$. glabrescens $(38.0 \%, n=50)$. Lower incidence of bleaching was recorded for $C$. jardinei $(26.3 \%$, $n=38)$ and $T$. geoffroyi $(23.2 \%, n=56)$, and particularly for $H$. australis $(17.6 \%, n=17)$ and $D$. axifuga $(11.5 \%$, $n=78$ ). For D. axifuga, bleaching incidence ranged from
10 to $17 \%$ with no obvious regional differences. For $E$. glabrescens, however, it was notable that only colonies collected from the GBR (NQ and CQ) exhibited bleaching (even when exposed to high light at ambient temperatures), whereas none of the colonies from WA exhibited major colour loss even when exposed to elevated temperature.

The best models to explain variation in the extent of colour loss recorded during this study included 'Species', 'Temperature', 'Light', and the interaction between 'Temperature' and 'Light' (Table 2). For M. lordhowensis, C. jardinei, T. geoffroyi and D. axifuga, bleaching (declines in colour saturation $>2$ ) was more prevalent and more pronounced for corals subject to warming, but the extent of colour loss was also exacerbated by exposure to high light (Fig. 2). Based on standardised mean differences, elevated temperature resulted in significant colour change for $C$. jardinei, T. geoffroyi, and D. axifuga, while high light intensity accounted for significant colour loss in M. lordhowensis and D. axifuga (Fig. 3). For E. glabrescens, the median level of colour loss was greatest in the high temperature and high light treatment, but bleaching was recorded across all treatments (Fig. 2). For H. australis, the incidence of bleaching was low across all treatments (Fig. 2).

\section{Survivorship}

Eighty-five (out of $257 ; 33.1 \%$ ) corals survived to the end of the experiment (150 d). Survivorship was lower $(21.3 \%)$ among corals subject to warming, than for corals maintained at ambient temperatures $(57.8 \%)$. However, there was also marked interspecific variation in the survival of corals between the two temperature treatments. The best model (based on $w A I C c$ ) for explaining variation in survivorship included the interaction between 'Species' and 'Temperature', but did not include light levels (Table 2). Post hoc pairwise comparisons showed that there were significant differences in survival between corals subject to warming versus ambient temperatures for $H$. australis $(p<0.001), M$. lordhowensis $(p<0.001), C$. jardinei ( $p=0.028)$, and E. glabrescens $(p<0.001)$; but not for $T$. geoffroyi $(p=0.791)$ and $D$. axifuga $(p=0.270)$.

Survivorship of the different coral species varied both in extent and timing. For $H$. australis and M. lordhowensis, survival declined sharply from day 1 to day 75 , during the treatment period for corals subject to warming (Fig. 4). Importantly, many colonies of $H$. australis died without exhibiting prior bleaching. For C. jardinei and E. glabrescens, there were also significant differences in survival with respect to temperature treatments, though this difference was most pronounced after the recovery period, on Day 150. For $C$. jardinei, differences in survival between temperature treatments were limited (92\% vs. $81 \%$ ) during 
Temperature: Ambient $\risingdotseq$ Hot

(a) Homophyllia australis

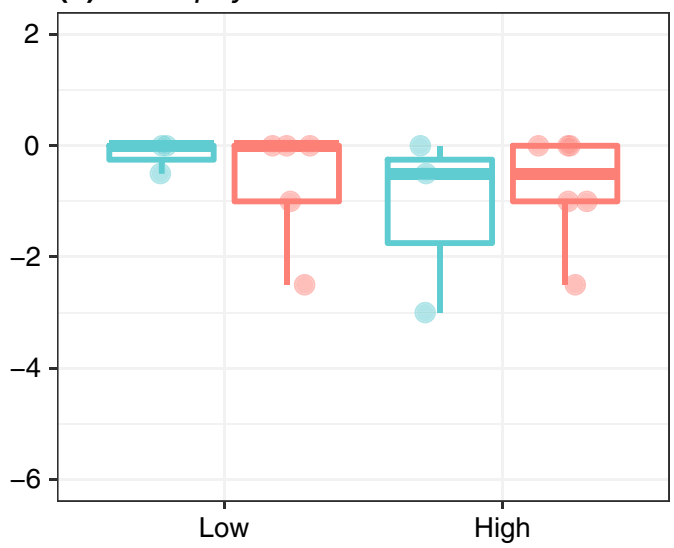

(c) Catalaphyllia jardinei

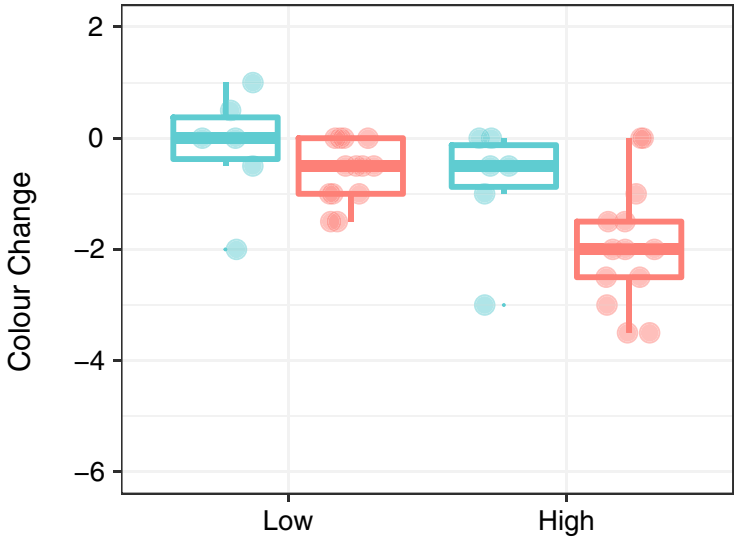

(e) Duncanopsammia axifuga

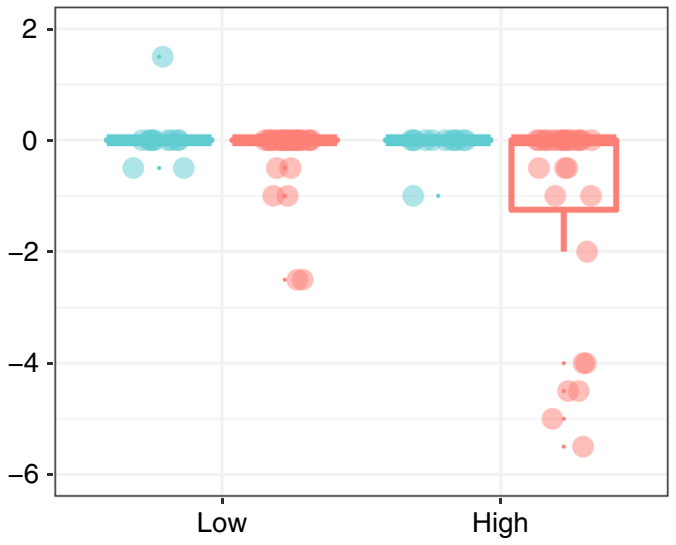

(b) Micromussa lordhowensis

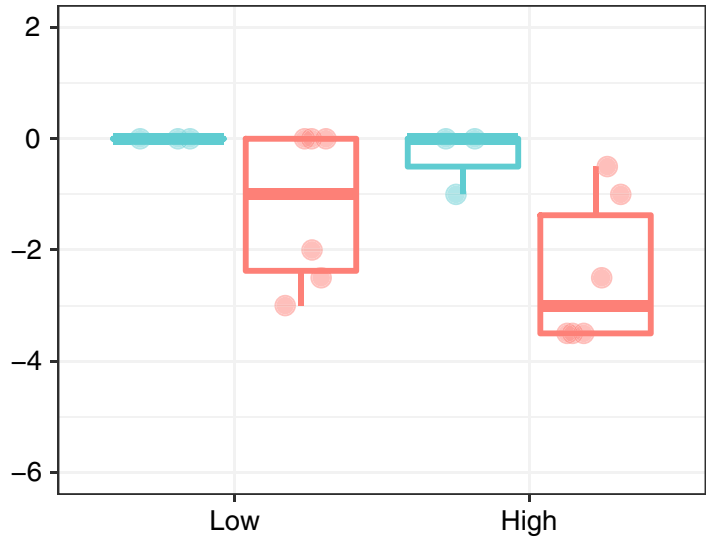

(d) Trachyphyllia geoffroyi

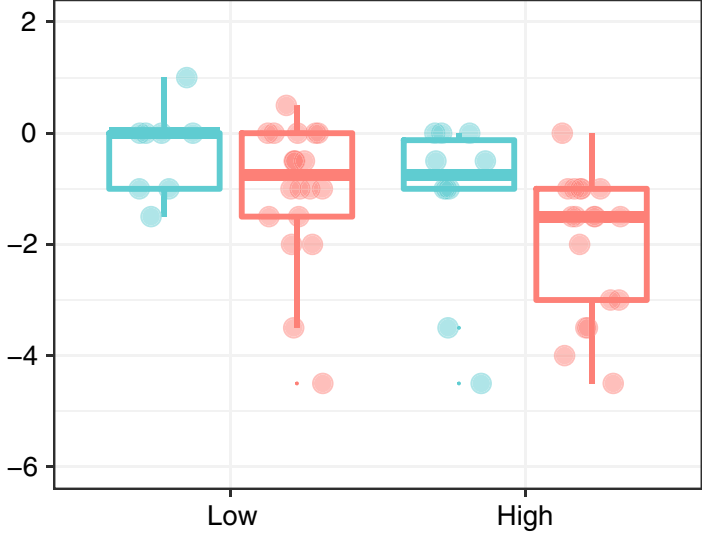

(f) Euphyllia glabrescens

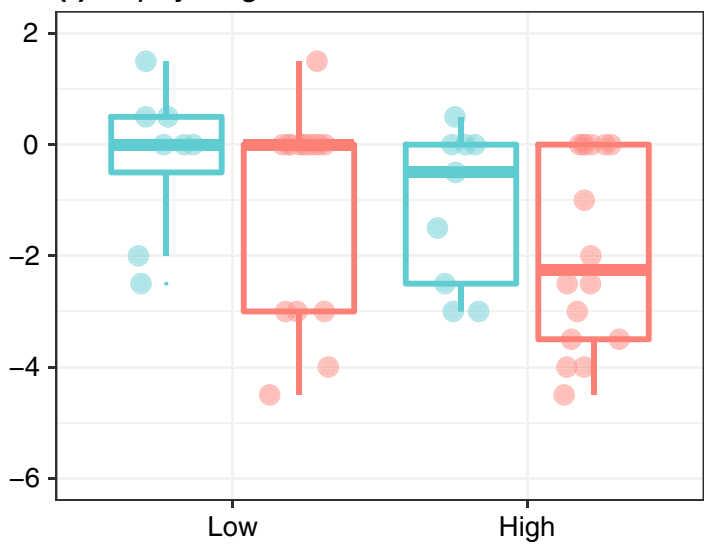

Light Intensity

Fig. 2 Boxplots showing species-specific colour change response to temperature and light intensity treatments. Plots show median (bold line), 25th and 75th percentile range (box), 5th and 95th percentile

the treatment period, from day 1 to day 75 , but overall survivorship (at day 150) was much lower for corals range (error bars), and jitter points (large coloured circles) pooled across temperature treatments for each light treatment

subjected to warming (19\%) compared to colonies maintained at ambient temperatures (75\%) (Fig. 4c). There was 
Table 2 Linear mixed-effects model (LMM) results for (a) survival and (b) colour change predicted as a function of 'Species', 'Temperature', 'Lighting', and their interaction effects

\begin{tabular}{|c|c|c|c|c|c|}
\hline Model & $d f$ & LL & $\mathrm{AICc}$ & wAICc & $\operatorname{Adj} R^{2}$ \\
\hline \multicolumn{6}{|l|}{ (a) Colour change } \\
\hline Species + temperature + light $+(1 \mid$ Tank $)$ & 10 & -421.3 & 863.5 & 0.347 & 0.229 \\
\hline Species + temperature $\times$ light $+(1 \mid$ Tank $)$ & 11 & -420.7 & 864.5 & 0.207 & 0.229 \\
\hline (1II Tank) & 3 & -432.5 & 871.1 & 0.008 & 0.131 \\
\hline Species $\times$ temperature $\times$ light $+(1$ । Tank $)$ & 26 & -410.0 & 878.2 & 0.000 & 0.253 \\
\hline \multicolumn{6}{|l|}{ (b) Survival } \\
\hline Species $\times$ temperature $+(1 \mid$ Tank $)$ & 14 & -177.3 & 384.3 & 0.922 & 0.535 \\
\hline Species $\times$ temperature $\times$ light $+(1$ । Tank $)$ & 26 & -179.3 & 416.8 & 0.000 & 0.555 \\
\hline (1। Tank) & 3 & -232.4 & 471.0 & 0.000 & 0.080 \\
\hline
\end{tabular}

All models include the tank as the random effect. Shown above are the degrees of freedom $(d f)$, maximum log-likelihood (LL), Akaike's information criterion corrected for small sample sizes (AICc), AICc weight (wAICc), and the adjusted $R^{2}\left(\operatorname{adj} R^{2}\right)$. Only models with $\triangle \mathrm{AICc}<2$ are shown, in addition to the saturated and null models, and are ordered by increasing AICc
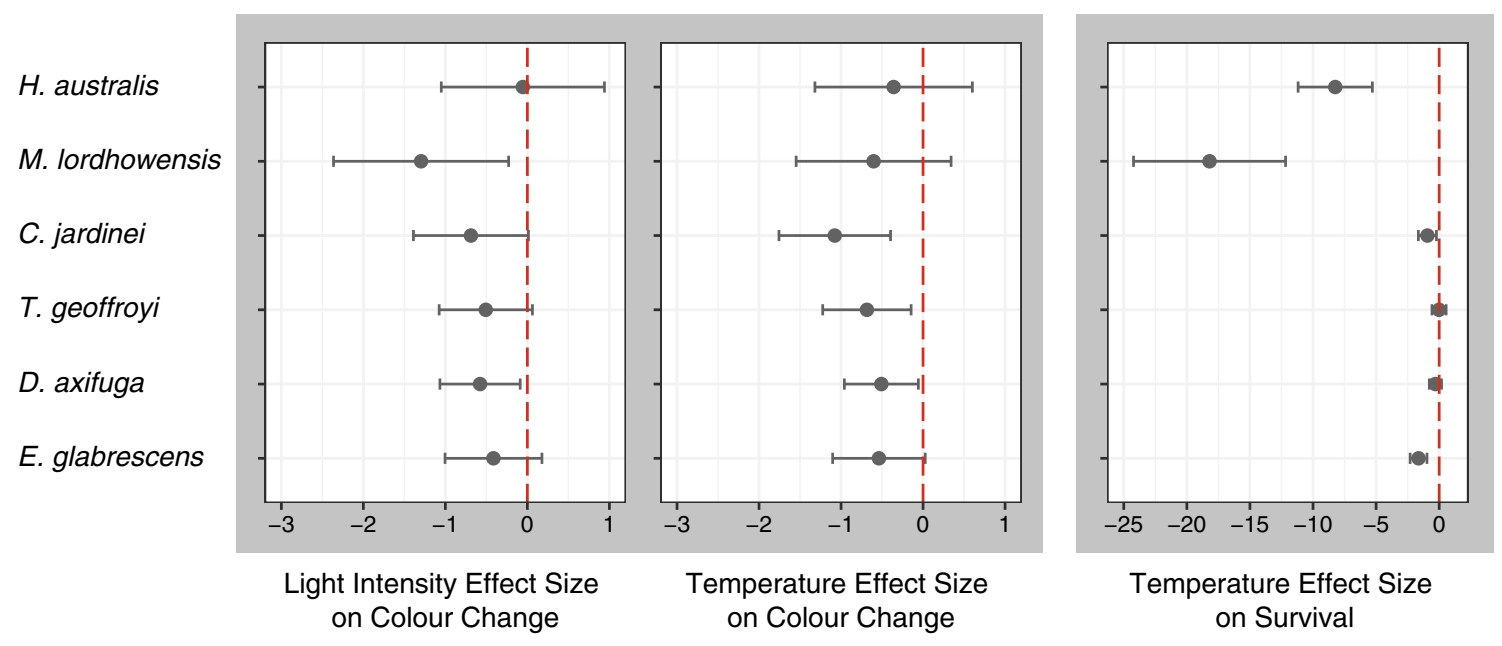

Fig. 3 Inter-specific differences in the effect of light intensity and temperature on colour change and the effect of high temperature on survival, based on Hedge's $G$ (i.e. effect size). Red dashed line

no difference in survival of $T$. geoffroyi or $D$. axifuga with respect to temperature treatments (Fig. 4). For D. axifuga, $<50 \%$ of corals survived $50 \mathrm{~d}$, and there was ongoing mortality throughout the subsequent treatment and recovery period (Fig. 4e). Survival of T. geoffroyi was much higher than for $D$. axifuga, but there were sustained levels of mortality throughout the experiment both for corals exposed to elevated temperatures and those maintained at ambient temperatures (Fig. 4).

Based on standardised mean differences, elevated temperature had a substantial negative effect on the survival of $H$. australis (as well as for M. lordhowensis, which was excluded from analyses due to zero variance in the 'Ambient' treatment, i.e. $100 \%$ survival) and E. glabrescens (Fig. 3). Warming also had a moderate effect on the survival of $C$. jardinei, but we did not observe any adverse effect on $T$. geoffroyi and D. axifuga. For those species that indicates zero effect, while points to the left of this line suggest a negative treatment effect on colour change or survival

did exhibit significant differences in survival between temperature treatments, interspecific differences in temperature sensitivity are also reflected in the time to median (50\%) survival, which was lowest for H. australis (51 d), but also $<75 \mathrm{~d}$ for M. lordhowensis (58 d) and E. glabrescens $(60 \mathrm{~d})$, and longest for $C$. jardinei $(118 \mathrm{~d})$.

\section{Discussion}

This study explored the temperature sensitivity and bleaching susceptibility of six different coral species $(H$. australis, M. lordhowensis, C. jardinei, T. geoffroyi, D. axifuga, and E. glabrescens), which are important target species for aquarium fisheries in QLD, WA and/or NT (DEEDI 2012; DPIR 2019; Newman et al. 2019). All six corals species exhibited bleaching to a greater or lesser 
Temperature: - Ambient $=\mathrm{Hot}$

(a) Homophyllia australis

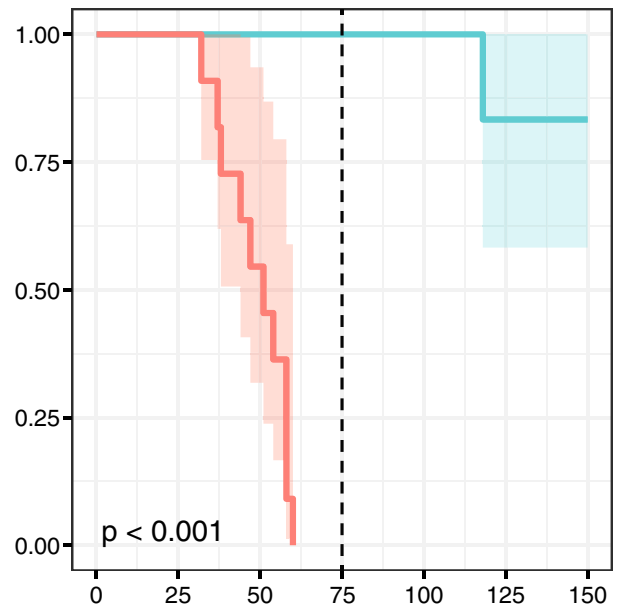

(c) Catalaphyllia jardinei

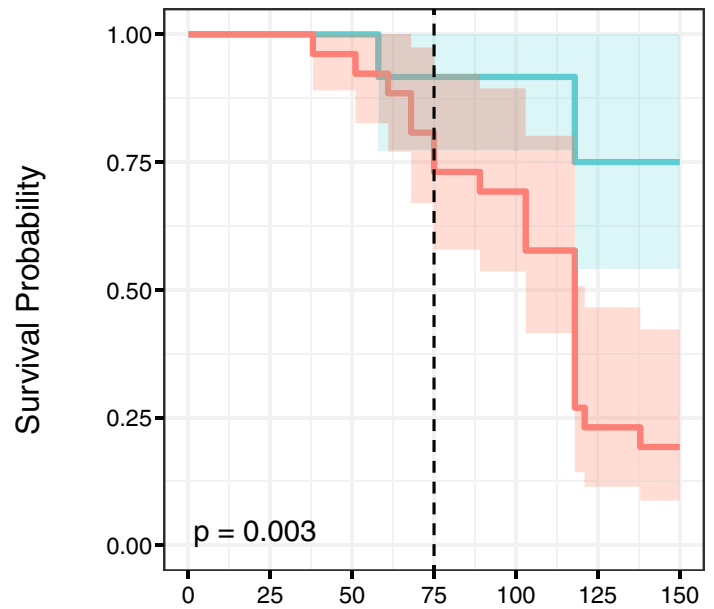

(e) Duncanopsammia axifuga

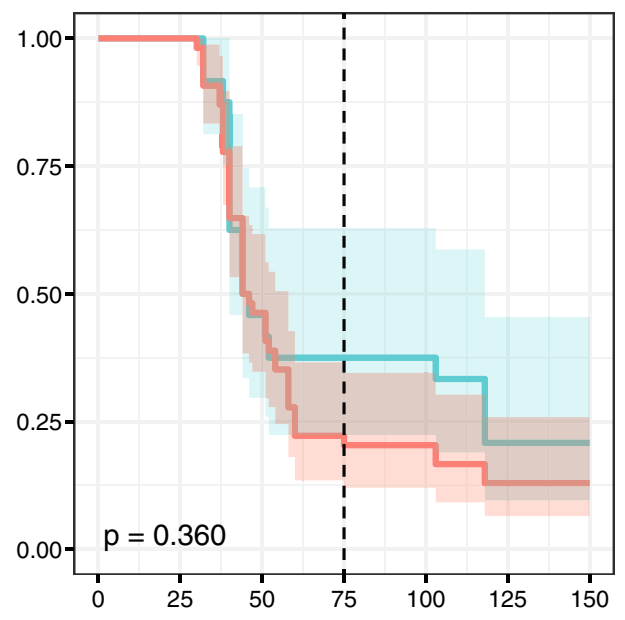

(b) Micromussa lordhowensis

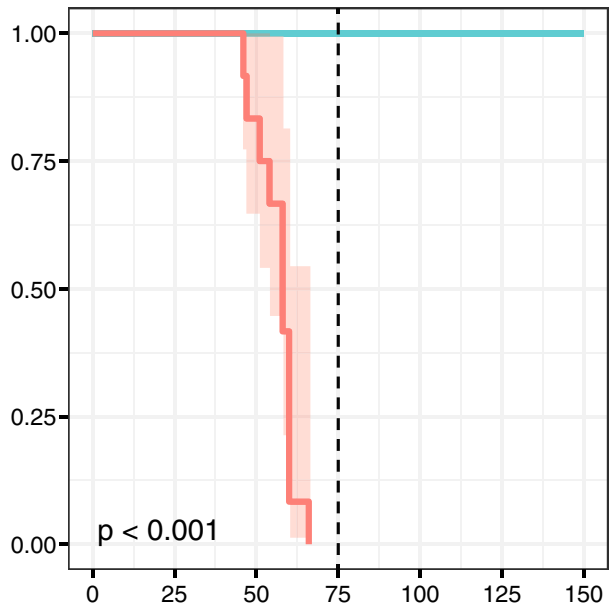

(d) Trachyphyllia geoffroyi

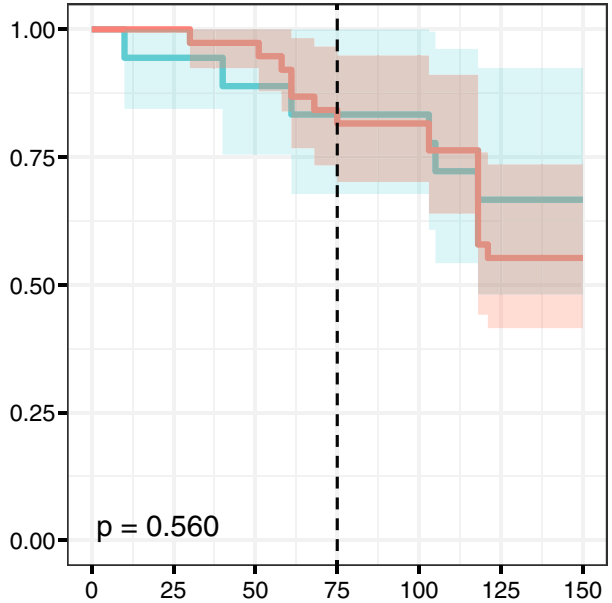

(f) Euphyllia glabrescens

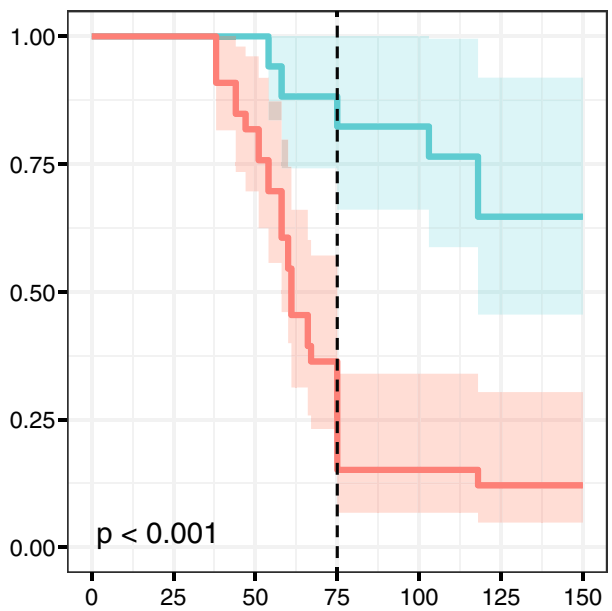

Time (days) 
४Fig. 4 Species-specific Kaplan-Meier-estimated survival probabilities under two temperature treatments. $p$ values for the log-rank test comparing survival curves between 'Ambient' and 'Hot' treatments are shown. Dashed line indicates termination of experimental treatments and start of recovery period at $75 \mathrm{~d}$

extent. Most notably, M. lordhowensis, C. jardinei, D. axifuga and T. geoffroyi exhibited significant colour loss (or bleaching) when exposed to elevated temperatures, and bleaching was exacerbated by high light intensity for $M$. lordhowensis and. D. axifuga. Even more concerning however, were the high levels of coral mortality $(>80 \%)$ recorded for $H$. australis, $M$. lordhowensis, E. glabrescens and $C$. jardinei when these corals were subjected to elevated temperatures. Maximum temperatures to which corals were exposed in this experiment $\left(32^{\circ} \mathrm{C}\right)$ were high, though corals living in the shallow subtidal and intertidal zones in northern Australia may be exposed to temperatures $\geq 32{ }^{\circ} \mathrm{C}$ during severe heatwaves (Moore et al. 2012) or in areas where water pools for extended periods at low tide (Dandan et al. 2015).

While bleaching is commonly recorded among scleractinian corals exposed to elevated temperatures and/or high light intensity, there are marked interspecific differences in the responses of corals (Loya et al. 2001; Hueerkamp et al. 2001; Dandan et al. 2015; Hughes et al. 2018b). In this study, $H$. australis was extremely sensitive to elevated temperature, whereby all colonies subjected to elevated temperatures had died within $60 \mathrm{~d}$, even though this species rarely exhibited bleaching. Rather than losing colour, tissues of $H$. australis would retract in response to warming (Fig. 1) prior to complete mortality of the corals. Conversely, T. geoffroyi exhibited a high incidence of bleaching when exposed to elevated temperatures, but low levels of mortality $(<50 \%)$. We observed yet another response for $C$. jardinei, for which, tissues would often detach from the underlying skeleton when subject to elevated temperature (Fig. 1). In many instances, the free-living tissue persisted ex situ and retained its colour intensity for the duration of the experiment. However, this is likely to be an experimental artefact, as free-living tissues of $C$. jardinei would likely be vulnerable to smothering or predation once dislodged in the wild. The only corals that exhibited more pronounced bleaching with increased light intensity were M. lordhowensis and D. axifuga, but this did not translate to differences in survivorship. Temperature and light act synergistically to influence bleaching susceptibility (Jokiel and Coles 1990), such that high turbidity in some nearshore environments may actually moderate bleaching-induced mortality during marine heatwaves (e.g., Fisher et al. 2019; Teixeira et al. 2019). However, this study shows that elevated temperatures are the predominant cause of bleaching and mortality, and the overriding concern for the corals considered in this study.

Interspecific differences in the environmental sensitivity and bleaching susceptibility among the six study species (H. australis, M. lordhowensis, C. jardinei, T. geoffroyi, D. axifuga, and E. glabrescens) may partially account for apparent differences in their abundance in different regions and habitats, or at least reflect the limited area over which corals were collected. Notably, the two coral species that were most susceptible to experimental warming (H. australis and $M$. lordhowensis) were provided exclusively from CQ, having been collected from the southern GBR in areas where these corals are relatively abundant. Both these corals are distributed further north on the GBR in much warmer waters (Veron et al. 2019), and it is possible that colonies from lower latitudes might exhibit greater resilience to elevated temperatures (sensu Hoegh-Guldberg 1999). Accordingly, E. glabrescens collected from WA exhibited much greater resilience to changing temperatures and light regimes, than conspecifics from the GBR. However, there was limited evidence of geographical variation in temperature sensitivity and bleaching susceptibility for D. axifuga (which was sampled from all four locations), nor for T. geoffroyi (sampled from WA, NQ and CQ). Although, this experiment did not specifically account for local temperature regimes from where individual corals were collected (and then test bleaching susceptibility against regionally specific bleaching thresholds), we would have expected that corals provided from lower latitudes and warmer water in WA and NT would be more resistant to elevated temperatures than corals from CQ (sensu Hoegh-Guldberg 1999). Ultimately, it would be best to explicitly account for the specific environmental conditions in habitats from where each individual coral was collected, but this was not possible given that corals were provided by licenced coral collectors and their individual provenance was only broadly known.

This study shows that at least some Australian aquarium coral fishery target species (specifically, $H$. australis, $M$. lordhowensis, E. glabrescens and C. jardinei) are susceptible to elevated temperatures, thereby highlighting the potential for sustained and ongoing environmental change to undermine the sustainability and viability of these fisheries. More importantly, there is an increasing shift in aquarium coral collections and exports towards small polyp coral species (mainly, Acropora spp., Dee et al. 2014; Barton et al. 2017) which are, in general, even more susceptible to environmental change (Baird and Marshall 2002; Pratchett et al. 2013; Hughes et al. 2018b; Burt et al. 2019), though vulnerability assessments will need to be undertaken for the specific species that are targeted and habitats from which they are taken. Similarly, results for this preliminary experimental study should not be used to 
infer relative or absolute vulnerability of the coral fishery target species to ocean warming, marine heatwaves, or changing environmental conditions. Rather, this study highlights the need for specific and targeted in situ monitoring for important stocks of coral fishery target species, to assess their vulnerability to fishery and fishery-independent effects.

Acknowledgements This study was funded in part by the Fisheries Research and Development Corporation (FRDC; Project 2014-029), with additional support from the WA Government Department of Biodiversity, Conservation and Attractions and also Pro-Vision Reef. In-kind support, through the provision of samples, was provided by many licensed coral collectors in WA, NT and QLD. Experimental studies were conducted at the JCU Marine Aquarium Research Facility (MARFU), and we are grateful to all MARFU staff for significant logistic support.

Open Access This article is distributed under the terms of the Creative Commons Attribution 4.0 International License (http://crea tivecommons.org/licenses/by/4.0/), which permits unrestricted use, distribution, and reproduction in any medium, provided you give appropriate credit to the original author(s) and the source, provide a link to the Creative Commons license, and indicate if changes were made.

\section{References}

Albert JA, Olds AD, Albert S, Cruz-Trinidad A, Schwarz AM (2015) Reaping the reef: provisioning services from coral reefs in Solomon Islands. Marine Policy 62:244-251

Anthony KR, Hoegh-Guldberg O (2003) Variation in coral photosynthesis, respiration and growth characteristics in contrasting light microhabitats: an analogue to plants in forest gaps and understoreys? Functional Ecology 17(2):246-259

Baird AH, Marshall PA (2002) Mortality, growth and reproduction in scleractinian corals following bleaching on the Great Barrier Reef. Mar Ecol Prog S 237:133-141

Barton JA, Willis BL, Hutson KS (2017) Coral propagation: a review of techniques for ornamental trade and reef restoration. Reviews in Aquaculture 9(3):238-256

Bates D, Mächler M, Bolker BM, Walker SC (2015) Fitting linear mixed-effects models using lme4. Journal of Statistical Software 67(1):1-48. https://doi.org/10.18637/jss.v067.i01

Buddemeier RW, Fautin DG (1993) Coral bleaching as an adaptive mechanism. Bioscience 43(5):320-326

Burnham KP, Anderson DR (2002) Model selection and multimodel inference: a practical information-theoretic approach. Springer, New York

Burt JA, Paparella F, Al-Mansoori N, Al-Mansoori A, Al-Jailani H (2019) Causes and consequences of the 2017 coral bleaching event in the southern Persian/Arabian Gulf. Coral Reefs 38(4):567-589

Camp EF, Schoepf V, Mumby PJ, Hardtke LA, Rodolfo-Metalpa R, Smith DJ, Suggett DJ (2018) The future of coral reefs subject to rapid climate change: lessons from natural extreme environments. Frontiers Mar Sci 5:4

Chou LM, Toh TC, Toh KB, Ng CS, Cabaitan P, Tun K, Goh E, AfiqRosli L, Taira D, Du RC, Loke HX (2016) Differential response of coral assemblages to thermal stress underscores the complexity in predicting bleaching susceptibility. PloS ONE 11(7):e0159755
Claar DC, Baum JK (2019) Timing matters: survey timing during extended heat stress can influence perceptions of coral susceptibility to bleaching. Coral Reefs 38(4):559-565

DAF (2018) Queensland fisheries summary-October 2018. State of Queensland, Department of Agriculture and Fisheries. https:// www.publications.qld.gov.au/dataset/e7f0da0a-3904-424b-ab48a63bf7157823/resource/873e3106-5993-4efb-a3dc-6b5dc1a1f2 f0/fs_download/queensland-fisheries-summary-report.pdf. Accessed 26 Nov 2019

Dandan SS, Falter JL, Lowe RJ, McCulloch MT (2015) Resilience of coral calcification to extreme temperature variations in the Kimberley region, northwest Australia. Coral Reefs 34(4):1151-1163

Dee LE, Horii SS, Thornhill DJ (2014) Conservation and management of ornamental coral reef wildlife: successes, shortcomings, and future directions. Biol Cons 169:225-237

DEEDI (2012) Annual status report 2011, Queensland Coral Fishery. State of Queensland, Department of Employment, Economic Development and Innovation. https://www.daf.qld.gov.au/_ data/assets/pdf_file/0010/76978/ASR_QCF2011.pdf. Accessed 26 Nov 2019

DPIR (2019) Northern Territory Aquarium Fishery Re-Assessment Report-August 2019. Department of Primary Industry and Resources, Northern Territory Government. 13p. http://www. environment.gov.au/system/files/consultations/6469a408-431f44a3-b1e3-4a711a9a84e4/files/nt-aquarium-re-assessment-2019. pdf. Accessed 26 Nov 2019

Fisher R, Bessell-Browne P, Jones R (2019) Synergistic and antagonistic impacts of suspended sediments and thermal stress on corals. Nature Comm 10(1):1-9

Garrabou J, Sala E, Linares C, Ledoux JB, Montero-Serra I, Dominici JM, Kipson S, Teixidó N, Cebrian E, Kersting DK, Harmelin JG (2017) Re-shifting the ecological baseline for the overexploited Mediterranean red coral. Sci Rep 7:42404

Glynn PW (1984) Widespread coral mortality and the 1982/83 El Nino warming event. Env Cons 11:133-146

Grottoli AG, Warner ME, Levas SJ, Aschaffenburg MD, Schoepf V, McGinley M, Baumann J, Matsui Y (2014) The cumulative impact of annual coral bleaching can turn some coral species winners into losers. Global Change Biol 20(12):3823-3833

Guest JR, Baird AH, Maynard JA, Muttaqin E, Edwards AJ et al (2012) Contrasting patterns of coral bleaching susceptibility in 2010 suggest an adaptive response to thermal stress. PLoS ONE 7:e33353

Gilmour JP, Cook KL, Ryan NM, Puotinen ML, Green RH, Shedrawi G, Hobbs JP, Thomson DP, Babcock RC, Buckee J, Foster T (2019) The state of Western Australia's coral reefs. Coral Reefs 38(4):651-667

Harriott VJ (2003) Can corals be harvested sustainably? AMBIO 32(2):130-134

Hedges LV (1981) Distribution theory for Glass's estimator of effect size and related estimators. J Ed Behav Stat 6:107-128

Heron SF, Maynard JA, Van Hooidonk R, Eakin CM (2016) Warming trends and bleaching stress of the world's coral reefs 1985-2012. Sci Rep 6:38402

Hobday AJ, Oliver EC, Gupta AS, Benthuysen JA, Burrows MT, Donat MG, Holbrook NJ, Moore PJ, Thomsen MS, Wernberg T, Smale DA (2018) Categorizing and naming marine heatwaves. Oceanography 31(2):162-173

Hoegh-Guldberg O (1999) Climate Change, coral bleaching and the future of the world's coral reefs. Mar Freshw Res 50:839-866

Hoey AS, Howells E, Johansen JL, Hobbs JPA, Messmer V, McCowan DM, Wilson SK, Pratchett MS (2016) Recent advances in understanding the effects of climate change on coral reefs. Diversity 8(2):12 
Hueerkamp C, Glynn PW, D’Croz L, Maté JL, Colley SB (2001) Bleaching and recovery of five eastern Pacific corals in an El Niño-related temperature experiment. Bull Mar Sci 69(1):215-236

Hughes TP, Kerry JT, Álvarez-Noriega M, Álvarez-Romero JG, Anderson KD, Baird AH, Babcock RC, Beger M, Bellwood DR, Berkelmans R, Bridge TC, Butler IR, Byrne M, Cantin NE, Comeau S, Connolly SR, Cumming GS, Dalton SJ, Diaz-Pulido G, Eakin CM, Figueira WF, Gilmour JP, Harrison HB, Heron SF, Hoey AS, Hobbs J-PA, Hoogenboom MO, Kennedy EV, Kuo C-y, Lough JM, Lowe RJ, Liu G, McCulloch MT, Malcolm HA, McWilliam MJ, Pandolfi JM, Pears RJ, Pratchett MS, Schoepf V, Simpson T, Skirving WJ, Sommer B, Torda G, Wachenfeld DR, Willis BL, Wilson SK (2017) Global warming and recurrent mass bleaching of corals. Nature 543(7645):373-377

Hughes TP, Anderson KD, Connolly SR, Heron SF, Kerry JT, Lough JM, Baird AH, Baum JK, Berumen ML, Bridge TC, Claar DC, Eakin CM, Gilmour JP, Graham NAJ, Harrison H, Hobbs JPA, Hoey AS, Hoogenboom M, Lowe RJ, McCulloch MT, Pandolfi JM, Pratchett MS, Schoepf V, Torda G, Wilson SK (2018a) Spatial and temporal patterns of mass bleaching of corals in the Anthropocene. Science 359(6371):80-83

Hughes TP, Kerry JT, Baird AH, Connolly SR, Dietzel A, Eakin CM, Heron SF, Hoey AS, Hoogenboom MO, Liu G, McWilliam MJ, Pears RJ, Pratchett MS, Skirving WJ, Stella JS, Torda G (2018b) Global warming transforms coral reef assemblages. Nature 556(7702):492-496

Jokiel PL, Coles SL (1990) Response of Hawaiian and other IndoPacific reef corals to elevated temperature. Coral Reefs 8(4):155-162

Kaplan EL, Meier P (1958) Nonparametric estimation from incomplete observations. J Am Stat Assoc 53:457-481

Kassambara A, Kosinski M, Biecek P (2017) survminer: Drawing Survival Curves using 'ggplot2'. $R$ package version 0.3.1

Lenth R, Singmann H, Love J, Buerkner P, Herve M (2018) Emmeans: estimated marginal means, aka least-squares means. Version 1(4):2

Loya Y, Sakai K, Yamazato K, Nakano Y, Sambali H, van Woesik R (2001) Coral bleaching: the winners and the losers. Ecology letters 4(2):122-131

Marshall PA, Baird AH (2000) Bleaching of corals on the Great Barrier Reef: differential susceptibilities among taxa. Coral Reefs 19(2): 155-163

McClanahan TR, Baird AH, Marshall PA, Toscano MA (2004) Comparing bleaching and mortality responses of hard corals between southern Kenya and the Great Barrier Reef, Australia. Marine Pollution Bulletin 48(3-4):327-335

Moore JA, Bellchambers LM, Depczynski MR, Evans RD, Evans SN, Field SN, Friedman KJ, Gilmour JP, Holmes TH, Middlebrook R, Radford BT (2012) Unprecedented mass bleaching and loss of coral across 12 of latitude in Western Australia in 2010-11. PLoS ONE 7(12):e51807

Montero-Serra I, Garrabou J, Doak DF, Ledoux JB, Linares C (2019) Marine protected areas enhance structural complexity but do not buffer the consequences of ocean warming for an overexploited precious coral. Journal of Applied Ecology 56(5):1063-1074

Newman SJ, Bruce C, Kalinowski P (2019) Statewide Marine Aquarium Fish and Hermit Crab Resources Status Report 2018. pp. 199-203. In: Gaughan DJ, Santoro K (eds.). Status reports of the fisheries and aquatic resources of Western Australia 2017/18: State of the Fisheries. Department of Primary
Industries and Regional Development, Western Australia, Perth, Australia. $240 \mathrm{pp}$

Pratchett MS, McCowan D, Maynard JA, Heron SF (2013) Changes in bleaching susceptibility among corals subject to ocean warming and recurrent bleaching in Moorea, French Polynesia. PLoS ONE 8(7):e70443

Queensland Government Department of Employment, Economic Development and Innovation (QDEEDI) (2009) A guide to the Queensland Marine Aquarium Fish Fishery and the Queensland Coral Fishery. $55 \mathrm{pp}$

Raymundo LJ, Burdick D, Hoot WC, Miller RM, Brown V, Reynolds T, Gault J, Idechong J, Fifer J, Williams A (2019) Successive bleaching events cause mass coral mortality in Guam, Micronesia. Coral Reefs 38(4):677-700

R Core Team (2019) R: a language and environment for statistical computing. R Foundation for Statistical Computing, Vienna, Austria. https://www.R-project.org/

Roelofs A, Silcock R (2008) A Vulnerability Assessment of Coral Taxa Collected in the Queensland Coral Fishery. Department of Primary Industries and Fisheries, Brisbane. $10 \mathrm{pp}$

Rhyne AL, Tlusty MF, Kaufman L (2012) Long-term trends of coral imports into the United States indicate future opportunities for ecosystem and societal benefits. Conservation Letters $5(6): 478-485$

Schwarzer G (2007) Meta: an R Package for Meta-Analysis. R News $7(3): 40-45$

Siebeck UE, Marshall NJ, Klüter A, Hoegh-Guldberg O (2006) Monitoring coral bleaching using a colour reference card. Coral Reefs 25(3):453-460

Skirving WJ, Heron SF, Marsh BL, Liu G, De La Cour JL, Geiger EF, Eakin CM (2019) The relentless march of mass coral bleaching: a global perspective of changing heat stress. Coral Reefs. 38(4):547-557

Teixeira CD, Leitão RL, Ribeiro FV, Moraes FC, Neves LM, Bastos AC, Pereira-Filho GH, Kampel M, Salomon PS, Sá JA, Falsarella LN (2019) Sustained mass coral bleaching (2016-2017) in Brazilian turbid-zone reefs: taxonomic, crossshelf and habitat-related trends. Coral Reefs 38(4):801-813

Therneau T (2015) A Package for Survival Analysis in S. version 2.38, https://CRAN.R-project.org/package=survival. Accessed 26 Nov 2019

Vargas-Angel B, Huntington B, Brainard RE, Venegas R, Oliver T, Barkley H, Cohen A (2019) El Nino-associated catastrophic coral mortality at Jarvis Island, central Equatorial Pacific. Coral Reefs. 38(4):731-741

Veron JEN, Stafford-Smith MG, Turak E, DeVantier LM (2019). Corals of the World. Accessed 22 November 2019, Version 001. http://coralsoftheworld.org/ [v0.01(Beta)]

Walker GA, Shostak J (2010) Common statistical methods for clinical research with $\mathrm{SAS}^{\circledR}$ examples. 3rd edition. Third. Cary, N.C., USA: SAS Institute Inc.

Wiedenmann J, D’Angelo C, Smith EG, Hunt AN, Legiret F-E, Postle AD, Achterberg EP (2013) Nutrient enrichment can increase the susceptibility of reef corals to bleaching. Nat Clim Chang 3:160-164

Wood E, Malsch K, Miller J (2012) International trade in hard corals: review of management, sustainability and trends. Proc. 12th Int. Coral Reef Symp. 1:9-13

Publisher's Note Springer Nature remains neutral with regard to jurisdictional claims in published maps and institutional affiliations. 